\begin{tabular}{|l|l|}
$\begin{array}{l}\text { Postprint } \\
\text { Version }\end{array}$ & 1.0 \\
\hline $\begin{array}{l}\text { Journal website } \\
\text { Pubmed link }\end{array}$ & https://mijn.bsl.nl/gezondheidsvaardigheden-waarom-doen-ze-er- \\
\hline toe/641406?redirect=1 \\
\hline DOI
\end{tabular}

This is a NIVEL certified Post Print, more info at http://www.nivel.eu

\title{
Gezondheidsvaardigheden: waarom doen ze er toe?
}

\author{
JANY RADEMAKERS ${ }^{1}$ \\ ${ }^{(1)}$ NIVEL, 1568, 3500, BN, Utrecht, The Netherlands
}

\begin{abstract}
SAMENVATTING
'Gezondheidsvaardigheden' is de gangbare Nederlandse vertaling voor de term 'health literacy'. Met gezondheidsvaardigheden worden de competenties van burgers en patiënten bedoeld in het vinden, begrijpen en toepassen van informatie op het gebied van gezondheid, ziekte en zorg. Meer uitgebreide definities omvatten ook psychologische en sociale aspecten, zoals motivatie, zelfvertrouwen en sociale steun. Mensen met lage gezondheidsvaardigheden hebben een slechtere gezondheid. Gezondheidsvaardigheden worden beschouwd als een belangrijke determinant van gezondheidsverschillen. Het NIVEL heeft recent een kennissynthese uitgebracht waarin belangrijke inzichten uit onderzoek naar gezondheidsvaardigheden worden samengevat. ${ }^{1}$ Deze forumbijdrage is geïnspireerd op die publicatie.
\end{abstract}

\begin{abstract}
Health literacy: why does it matter? Health literacy are competencies that people need to find, understand and apply information regarding health, illness and care. Broader definitions include psychological and social aspects. Of Dutch adults, three out of ten have an inadequate or problematic health literacy level. Lower health literacy has a negative impact on health outcomes. Health literacy is regarded by the WHO as an important determinant of health disparities. In the Netherlands, health literacy has only fairly recently become a topic of public debate. More research is needed into the (cost-)effectiveness of health literacy interventions. Also barriers for implementation require further attention.
\end{abstract}

\section{WAT ZIJN GEZONDHEIDSVAARDIGHEDEN?}

Er zijn veel verschillende definities van gezondheidsvaardigheden. ${ }^{2}$ Sommige leggen vooral de nadruk op functionele competenties (lezen, rekenen) en op cognitieve aspecten van informatieverwerking (begrijpen, beoordelen). Andere zijn breder en 
kijken ook naar de motivatie van mensen om iets aan hun gezondheid of aan zelfmanagement te willen doen. En als ze dat willen, of ze bijvoorbeeld het zelfvertrouwen en de sociale vaardigheden hebben om dit ook in de praktijk te brengen, zelf of met de hulp van anderen. Een definitie die zich vooral beperkt tot de cognitieve aspecten is die van het Europese HLS-EU onderzoek: ${ }^{2}$,

'Gezondheidsvaardigheden zijn de vaardigheden van individuen om informatie over gezondheid te verkrijgen, te begrijpen, te beoordelen en te gebruiken bij het nemen van gezondheidsgerelateerde beslissingen'. Een voorbeeld van een bredere definitie van gezondheidsvaardigheden is die van de WHO: 'The cognitive and social skills which determine the motivation and ability of individuals to gain access to, understand and use information in ways to promote and maintain good health'. Uit het HLS-EU onderzoek dat in acht Europese landen werd uitgevoerd blijkt dat het in Nederland relatief goed gesteld is met de gezondheidsvaardigheden. ${ }^{3}$ Toch wordt ook in ons land het niveau van gezondheidsvaardigheden bij bijna drie op de tien volwassenen $(29,7 \%)$ gecategoriseerd als problematisch of zelfs inadequaat. Bijna één op de tien Nederlanders geeft zelf aan veel moeite te hebben met informatie over gezondheidszorg en -bevordering. ${ }^{5}$ Vooral ouderen, lager opgeleiden en mannen doen het in dit opzicht slechter. Het is belangrijk te bedenken dat mensen hun vaardigheden in een bepaalde context moeten gebruiken.

Gezondheidsvaardigheden worden belangrijker naarmate die context ingewikkelder is. Medische informatie (bijvoorbeeld in folders, bijsluiters van medicijnen en op internet) en het taalgebruik van zorgverleners zijn vaak erg gecompliceerd. Ook organisatorische aspecten van de zorg zoals de bewegwijzering in ziekenhuizen of een afsprakensysteem via de computer kunnen voor mensen met lagere gezondheidsvaardigheden een probleem vormen.

\section{DE RELEVANTIE VAN GEZONDHEIDSVAARDIGHEDEN VOOR DE VOLKSGEZONDHEID}

Mensen met lagere gezondheidsvaardigheden rapporteren zelf vaker een matige of slechte gezondheid en hebben ook objectief minder goede gezondheidsuitkomsten. ${ }^{6}$ Daarbij gaat het om het vaker voorkomen van bepaalde ziekten (zoals astma, diabetes, kanker, hart- en vaatziekten, psychische aandoeningen) en om een grotere sterftekans op jongere leeftijd. In de NIVEL-kennissynthese worden een aantal wegen beschreven waarlangs gezondheidsvaardigheden invloed hebben op deze uitkomsten: (1) niveau van kennis en informatie, (2) leefstijl, (3) zorggebruik en toegang tot de zorg, (4) communicatie met de zorgverlener en (5) zelfmanagement en medicijngebruik. In het algemeen functioneren mensen met lagere gezondheidsvaardigheden slechter op deze domeinen. Ze hebben minder kennis van hun lichaam en over gezondheid en ziekte. Ze kunnen minder goed uit de voeten met de schriftelijke informatie (op papier of internet) die op dat gebied beschikbaar is. Ze hebben over het geheel genomen een minder gezonde leefstijl en nemen minder vaak deel aan preventie- en screeningsprogramma's. Omdat ze niet goed kunnen beoordelen wanneer ze een gezondheidsprobleem zelf kunnen oplossen en wanneer niet, gaan ze vaker dan nodig naar de huisarts of eerste hulp. Dit leidt tot onnodige zorgkosten. Communicatie is een ander probleem. Veel mensen met lage gezondheidsvaardigheden schamen zich voor het feit dat ze niet goed kunnen lezen of de dokter niet begrijpen. In het consult met een arts nemen zij minder actief deel aan het gesprek, voelen ze zich onzekerder en ervaren ze ook meer barrières om met de arts in gesprek te gaan. ${ }^{7}$ Mensen met lage gezondheidsvaardigheden blijken 
verder minder goed in staat om zelfmanagementtaken uit te voeren en hebben meer moeite met het correct innemen van hun medicijnen. De American Medical Association concludeert op basis van Amerikaans onderzoek dat gezondheidsvaardigheden een sterkere voorspeller van iemands gezondheid zijn dan leeftijd, inkomen, werk, opleidingsniveau of culturele achtergrond. ${ }^{8}$ De WHO beschouwt gezondheidsvaardigheden als een belangrijke determinant van gezondheidsverschillen. ${ }^{9}$ In het kader van het terugdringen van gezondheidsachterstanden zou een grotere aandacht voor gezondheidsvaardigheden daarom opportuun zijn.

Daarbij komt dat in het huidige Nederlandse gezondheidszorgbeleid een steeds grotere nadruk wordt gelegd op de eigen actieve rol en verantwoordelijkheid van de burger en patiënt. Het gaat hierbij bijvoorbeeld om het maken van keuzes (voor een zorgaanbieder of -verzekeraar), gedeelde besluitvorming in de spreekkamer en zelfmanagement. E-health wordt gezien als een belangrijk instrument. Ook de organisatie van en regie over de eigen zorg wordt steeds belangrijker. Mensen met lagere gezondheidsvaardigheden hebben meer moeite met die rol. Zij laten de keuze voor een ziekenhuis liever over aan de huisarts ${ }^{10}$ en zijn minder goed in staat om zelfmanagementtaken uit te voeren. In Groot-Brittannië wordt daarom gewaarschuwd dat een al te eenzijdige nadruk op de individuele verantwoordelijkheid van burgers in dit verband kan leiden tot een verdere polarisatie in de samenleving en daardoor tot grotere gezondheidsverschillen. ${ }^{11}$

\section{AANKNOPINGSPUNTEN VOOR VERBETERING}

\section{Rekening houden met verschillen}

De aandacht voor het thema gezondheidsvaardigheden is in Nederland nog relatief recent. Uit onderzoek aan het begin van deze eeuw was al wel gebleken dat er in Nederland ongeveer 1,5 miljoen laaggeletterden waren. Dit leidde tot initiatieven die zich richtten op de alfabetisering van deze groep (oprichting van de Stichting Lezen \& Schrijven; Aanvalsplan Laaggeletterdheid 2006-2010). De link met gezondheid werd pas een aantal jaren later gemaakt. ${ }^{12}$ In 2010 werd in Nederland de alliantie Gezondheidsvaardigheden opgericht, een netwerkorganisatie die tot doel heeft het onderwerp op de agenda te krijgen en de samenwerking en uitwisseling tussen de netwerkpartners te bevorderen (www.gezondheidsvaardigheden.nl). Een jaar later volgde een rapport van de Gezondheidsraad waarin gezondheidsvaardigheden onder de aandacht van de Minister werden gebracht. ${ }^{13}$ Een belangrijke boodschap daarin was dat in zorg en beleid niet langer moest worden gedacht in termen van 'de patiënt' of 'de burger', maar dat er meer oog zou moeten zijn voor de verschillen tussen wat mensen zelf kunnen. Minister Schippers erkende het belang van gezondheidsvaardigheden, maar zag in de aanpak ervan toch primair een rol weggelegd voor het veld.

\section{Interventies op maat}

In Nederland, net als in de rest van Europa, waren activiteiten op dit gebied in eerste instantie gericht op het in kaart brengen van het aantal mensen met lage gezondheidsvaardigheden (zoals bijvoorbeeld in de HLS-EU studie). Ook werd in onderzoek veel aandacht besteed aan de vertaling en validatie van vragenlijsten en screeners waarmee zowel onderzoekers als clinici gezondheidsvaardigheden in hun doelgroep konden meten. Inmiddels is de tijd rijp voor verdere stappen. 
In de Verenigde Staten zijn al diverse interventies ontwikkeld om het niveau van gezondheidsvaardigheden bij individuen en groepen te bevorderen. ${ }^{6}$ Deze interventies blijken in een aantal gevallen positieve effecten te hebben op diverse uitkomsten: een gezondere leefstijl, gebruik van gezondheidsinformatie en keuzehulpen bij het nemen van beslissingen, zelfmanagement, therapietrouw en klinische indicatoren. Sommige interventies zijn rechtstreeks gericht op het verbeteren van de vaardigheden, andere zijn op maat gemaakt voor mensen met verschillende niveaus ('tailored interventions'). Een voorbeeld van de eerste soort zijn interventies die zich in een aantal bijeenkomsten of informatie via de computer richten op het beter begrijpen en interpreteren van gezondheidsinformatie, of op kennis over het eigen lichaam. Ook technieken die mensen met lage gezondheidsvaardigheden ondersteunen bij het zich voorbereiden op een gesprek met de zorgverlener passen in deze categorie. Op maat gemaakte interventies proberen meer persoonsgericht te werken, bijvoorbeeld door bij zelfmanagementondersteuning aan te sluiten bij de wensen, behoeften en mogelijkheden van de patiënt. In Europa lopen we in dit opzicht achter. Al worden er in veel landen wel initiatieven ondernomen, er bestaan nog maar weinig interventies waarvan de effectiviteit echt goed onderzocht is. Daarbij gaat het zowel om de impact op gezondheidsvaardigheden en -uitkomsten als om de kosteneffectiviteit. Een belangrijke aanbeveling is dan ook om dergelijke individuele en groepsinterventies in Nederland te ontwikkelen en door middel van goed opgezet onderzoek te evalueren. Daarbij gaat het zowel voor interventies in de klinische setting als voor preventie en gezondheidsbevordering.

\section{Organisatie en professionals moeten anders leren werken}

Naast het verbeteren van het niveau van gezondheidsvaardigheden van individuen en/of groepen komen we ook weer terug bij de context. Immers, als men in activiteiten rondom preventie, gezondheidsbevordering en zorg beter aansluit bij de behoeften en mogelijkheden van mensen met lagere gezondheidsvaardigheden dan worden de taken die aan deze groep gesteld worden eenvoudiger en beter haalbaar. Daarbij gaat het vooral om communicatie en informatie (eenvoudige geschreven teksten, gebruik van beeldmateriaal, mondelinge communicatie die aansluit bij het niveau van mensen met lage gezondheidsvaardigheden). Maar ook om een adequate organisatie en inrichting van de instelling. In de Verenigde Staten is het concept van de 'health literate care organisation' geïntroduceerd waar men zich op alle niveaus en in alle werkzaamheden bewust richt op de verbetering van de zorg aan mensen met lage gezondheidsvaardigheden. ${ }^{14}$

In Nederland hebben verschillende organisaties (LHV, Vilans) toolkits of trainingen voor zorgverleners ontwikkeld. Ook op de website van de Alliantie Gezondheidsvaardigheden zijn tips en materialen te vinden. Die worden echter allemaal maar beperkt gebruikt. Een mogelijke reden is het bewustzijn dat hier sprake is van een probleem in ons land nog onvoldoende ontwikkeld is. Maar ook tijdgebrek, andere prioriteiten of gebrek aan vaardigheden aan de kant van de zorgverlener zouden een rol kunnen spelen. Eigenlijk weten we niet goed wat de barrières zijn voor implementatie van deze interventies op het niveau van de professional of de instelling. Ook dit is een belangrijk onderwerp voor toekomstig onderzoek. 
Rademakers, J. Gezondheidsvaardigheden: waarom doen ze er toe? TSG: Tijdschrift voor Gezondheidswetenschappen: 2015, 93(3), 89-91

\section{LITERATUUR}

1. Rademakers J. Gezondheidsvaardigheden; niet voor iedereen vanzelfsprekend. Utrecht: NIVEL, 2014. http://www.nivel.nl/sites/default/files/bestanden/Kennissynthese-

Gezondheidsvaardigheden-2014.pdf

2. Sørensen K, Van den Broucke S, Fullam J et al. on behalf of the European Health literacy consortium. Health literacy and public health: A systematic review and integration of definitions and models. BMC Public Health 2012;12:80.View ArticlePubMed CentralPubMed

3. Pelikan J, Röthlin F, Ganahl K, on behalf of the HLS-EU consortium. Comparative report on health literacy in eight EU member states (The European Health literacy Project HLSEU 2009-2012). Wien: HLS-EU consortium, 2012.

4. Nutbeam D. Health Promotion Glossary. Geneva, WHO Division of Health Promotion, Education and Communications, 1998.

5. Heide I van der, Rademakers J, Schipper $M$ et al. Measuring the health literacy skills of Dutch adults; a cross sectional survey. BMC Public Health 2013;13:179.View Article

6. Berkman ND et al. Health Literacy Interventions and outcomes: An updated systematic review. AHRQ Publication (Rockville, USA) No. 11-E006, 2011.

7. Henselmans I, Heijmans M, Rademakers J, Dulmen S van. Participation of chronic patients in medical consultations: patients' perceived efficacy, barriers and interest in support. Health Expectations: 2014, DOI: 10.1111/hex.12206.

8. Ad Hoc Committee on Health literacy for the Council on Scientific Affairs, American Medical Association. Health literacy: report of the Council on Scientific Affairs. JAMA 1999;281):552-7.99

9. WHO Commission on the Social Determinants of Health. Achieving health equity: From root causes to fair outcomes. Geneva: WHO, 2007.

10. Rademakers J, Nijman J, Brabers A, Jong J de, Hendriks $M$. The relative effect of health literacy and patient activation on provider choice in the Netherlands. Health Policy 2014;114:200-6.View ArticlePubMed

11. Dixon A, Le Grand J. Is greater patient choice consistent with equity? The case of the English NHS. J Health Services Research Policy 2006;11:162-6.View Article

12. Twickler M, Hoogstraten $E$, Reuwer $A$ et al. Laaggeletterdheid en beperkte gezondheidsvaardigheden vragen om een antwoord in de zorg. Ned Tijdschr Geneesk 2009;153:A250.

13. Gezondheidsraad. Laaggeletterdheid te lijf. Signalering ethiek en gezondheid, 2011/1. Den Haag: Centrum voor ethiek en gezondheid, 2011.

14. Brach C, Keller D, Hernandez L et al. Ten Attributes of Health Literate Health Care Organizations. IOM Roundtable on Health Literacy, 2012. http://www. ahealthyundersta nding.org/Portals/0/Documents1/IOM_Ten_Attributes_HL_Paper.pdf 